\title{
An Expedition
}

\section{Stephen Nunn}

I stood with my grandfather beside the car. We were waiting for my grandmother. When she came out of the house, she had with her a large covered basket, and, as she approached the car, my grandfather opened the back door for her and she put the basket into the back seat. The back seat was already crowded with hampers and cardboard boxes and paper bags and similar receptacles, all containing food and provisions for my grandmother's brother. She had been working on these things for weeks. When she had got the basket in, she stood back and made a signal for me to get in too, which I did, but not comfortably. With all the stuff that was already in the car, there was hardly room for me to sit at all, let alone sit comfortably.

They got into the front seat. Just before he turned the key, my grandfather said, "Hilda, if you want, I can take all this up to Treach myself. You don't have to go, if you don't want to."

My grandmother did not turn to look at him, but, gazing straight forward through the windshield toward the house, she said, "Well, I am going, Arthur."

"Have it your own way," he said. He started the car and turned around in the yard, and we drove down to the highway.

I sat in the back seat with the stuff and looked at the two of them. They wore, instead of their regular farm clothes, what they would have worn, not to church, which they never attended, but to, say, a Fourth of July picnic. My grandfather had on a tie and his straw hat, and my grandmother had on a good dress and high heels. They looked very strange to me. I had on clean jeans, and they made me feel stiff. I hadn't wanted to come, anyway.

Nobody talked. That was strange.

After about an hour we crossed the Tennessee border into Kentucky, where we drove along on some of those old highways that run around in the hills. The trees had not turned yet, but this far north they were beginning to think about it. Still it was hot, and the back of my shirt was wet where it rested against the plastic of the seat cover, and this-this and my cramped position, and those 
jeans, and the fact that after all I did not want to come anyway-made me unhappy.

"I don't see why I had to come," I said. "I wanted to stay home, anyway."

The front seat did not answer me.

I repeated, "I don't see why I had to come. Why couldn't I stay home?"

Normally my grandmother would have answered such a question, but now she said nothing. After a brief pause, therefore, my grandfather said:

"Be quiet."

I did not think this was an answer. While I was thinking about a way to get around it, we turned off the highway onto a small road paved only with gravel. Here the land increased in ruggedness, and the road looked small and uncertain, afraid of the terrain around it. I considered the change of venue sufficient excuse to speak.

"How much further is it?" I asked.

"Not far," said my grandfather.

"But how far?"

"Not very far. Be quiet," he said.

So we went for some distance before I spoke again. Instead I watched. The road did not gut the land, did not ram through the hills and kill them, but instead followed their forms, leaving only surface wounds, rising and falling with them. We rounded a curve that bore left and slightly up. Just off the road, a stand of trees went up and over the rise, like a saddle. It was a sorry stand of trees, and in the middle of it was a pickup truck, or rather a remnant of one, which was sorry in its own right. It lay rather than stood, because all four of its wheels had been removed, and from appearances it had lain there like that for some time, and now it was just a rusted-out hulk, hardly even the hulk of a pickup truck anymore-its quality of being one not of pickup truckness but of hulkness.

When we discovered this hulk my grandmother spoke for the first time since we had left home.

"He just leaves them there," she said softly.

"Who leaves them?" I said. "Uncle Treach? Why does he leave them?"

My grandmother did not answer. She was silent again and staring straight ahead. There was such a silence after this question of mine that I began to doubt that she had ever spoken, or that I had. But I was reassured by my grandfather, who said, "He leaves them because they break down."

"But why doesn't he fix them?" I asked.

"I suppose," said my grandfather, "that he does not wish to."

We passed several more hulks. Some were other pickups, a couple were cars, and there was even an occasional piece of farm machinery. All of them were old.

"All of these aren't Uncle Treach's, are they?" I asked my grandfather.

"Yes," he said.

Before the woods on the hill, the land on either side of the road had been, though wounded, fruitful. From the woods on, though-Uncle Treach's land-it was ragged and unkempt. The further in we drove, the greater was the disorder of the land. Even the road seemed to deteriorate and became so full of ruts and 
potholes that, on an even slightly muddy day, it would have been impassable. Because of the hilliness and curviness of the road, you could not see very far in front of you, so it was not until we topped the next to last hill that I saw the house, where it stood on top of the last one. And there, at the house, the road, which had struggled along so unwillingly and so painfully for so long, just laid down and died.

I knew this for the house where my grandmother and Uncle Treach both had been born. It hardly seemed a house now. The yard was patchy, with only scattered spots of grass in a large stretch of dust. The house was weathered gray, and the roof sagged where it had not fallen in completely. Another old car was up on blocks in the side yard, and beside that a large cabinet with its glass front busted out. Beside that a large icebox lay tipped on its side. The only thing that looked like it worked at all in that yard was a tractor parked up against the house and half obscured in the shadow that fell out from inside the porch. Barbed wire ran around it all.

At the sound of our car, half a dozen hounds and curs came from under the house and ran yapping up to the fence. My grandfather ran the car up to the fence and got out, calling to some of the dogs by name and soothing them down. They seemed to know him and they quieted and nuzzled for him through the fence wires. He pet them briefly, looking up toward the house. No one came out.

My grandfather called out in a voice that did not question but simply hailed: "Hey, Treach Phillips!"

There was no response. He called again.

"He may not be here, Sam," said my grandmother from the car, where she and I still sat.

"He's here," my grandfather told her. "You got company, Treach!"

I got out of the car and ran over beside my grandfather, but my grandmother remained as she had been, looking straight ahead, now at the old house where she was born.

My grandfather called again.

The door of the house opened, and he came out on the porch. Because of the shadow, he was not very visible, but I could see that he was wearing some sort of baggy work clothes and a hat or cap. He did not say anything to my grandfather, but just stood on the porch, bracing himself with his hands on two posts, leaning forward, looking out across the yard at us.

"You care if I come in, Treach?" asked my grandfather, reaching around behind the gate to undo the latch.

Uncle Treach said nothing. My grandfather opened the gate and went through, the dogs crowding and jumping up around him in greeting. He pet them disinterestedly again, keeping his eyes on Uncle Treach. I slipped through with him. He latched the gate behind him and stood just inside the fence, not going closer to the house, his arms folded, regarding Uncle Treach. I stood a little behind him in his shadow.

From the porch Uncle Treach pointed at me with his head and asked, "Who is that?"

I don't believe my grandfather knew I was with him because he seemed sur- 
prised when he looked down where Uncle Treach had indicated and found me there. However, he did not seem angry.

"Arthur Jr.'s boy, Treach," he answered.

"My great nephew," said Uncle Treach.

He took a couple of steps down from the porch and as he came into the light I saw that he was a tall thin man. It was thinness that had made his clothes appear so baggy. He was very old and he did not move fast, but he did not hobble. He moved solidly. As he advanced toward us, my grandfather left our position by the fence and went forward to meet him. I followed. As we got closer to each other, I saw that Uncle Treach was extremely dirty and dishevelled. His clothes were filthy stiff. Grime was caked under his fingernails. His hair was shaggy around his cap and his gray and black beard was not cultivated but was simply the result of not shaving.

My grandfather stopped a few feet from him. Uncle Treach also stopped.

"Yeah," said my grandfather, "he's your great nephew."

Uncle Treach looked down and considered me in this light.

"Arthur Jr. was always a fine boy," he said.

"Yes," said my grandfather.

Uncle Treach moved to get a different view of me. "He favors him," he said.

"He does," said my grandfather.

"Can he split kindlin?? Arthur Jr. was always good for splittin' kindlin'."

"I don't think he's ever split kindlin'."

Uncle Treach smiled. "I need plenty," he said. "Does he want practice?"

My grandfather laughed. I was not sure what was happening, and I didn't.

Uncle Treach said, "I've got something to show you all. Come on." He turned and was leading us over in the direction of the only hopeful looking thing in his yard, the tractor, when he caught sight of the car. My grandmother had not gotten out, but evidently Uncle Treach saw her through the glass, because he stopped and looked hard at the car for a few seconds and then his hands tightened at his sides into fists. I could not see his face, but his voice accused my grandfather.

"You brought her with you."

"She's brought you something for the winter, Treach, like every year," said my grandfather.

Uncle Treach did not turn around but answered with his back to us. "Sam," he said. It was the first time I had heard him use my grandfather's name. "You son of a bitch." His voice sounded about to break. I thought perhaps he would cry, but he didn't. He did not turn around either; he just stood and spat words backwards at my grandfather in his broken voice.

"You listen to me, Arthur," he said. "You listen to me."

He paused. My grandfather said nothing, and he continued.

"I told you many times I don't want her up here on my farm. I told you keep her down there. I told you keep yourself down there too and leave me alone. But no. But no. I got to be done for. Little Treach is out here by hisself and he got to be done for. I got to be done for by every asskissin' member of this whole sonabitchin' family, and I-" 
"The farm is Hilda's, too," put in my grandfather.

For a moment Uncle Treach was silent. Then he turned around and looked right in my grandfather's face and screamed at him. There were no words. At the apex of this wordless scream he tore his cap off and threw it down on his piebald ground, and then he was quiet. His uncovered hair was like a bush. His scream hung in the air. He continued for a few moments to gaze at my grandfather with his mouth open, as though he were screaming still outside our register of hearing. Then he turned and began to walk back toward the house, just as he had walked away from it leading us.

"We're gonna bring in the stuff now, Treach," my grandfather said after him.

Uncle Treach kept right on walking.

"You want us to bring it up to the porch and set it there for you?"

Uncle Treach kept right on walking.

"You want us to bring it in the house for you, then?"

"Try it," said Uncle Treach over his shoulder, still walking.

My grandfather smiled just a little. He guided me back out through the gate and said, "Come on, Art, let's get it unloaded."

We began to unload the stuff from the side of the car opposite where I had sat, because that was the side loaded nearer to a door. When my grandfather leaned in to get a load, my grandmother asked, "Did he use language, Art?"

My grandfather answered, "No."

We made several trips. Once we both carried the same load, a big cardboard box of jellies and preserves and some cartons of eggs. My grandfather was holding his end at waist level, so I had to hold mine up at shoulder level to keep it riding even. My grandfather took this occasion to speak to me over the top of the box, even though, since the top of the box was above my head, he couldn't see me. He said, "You know, your daddy and I used to do this very same thing when he was your age."

I did not say anything, and he didn't say anything else either.

Finally one whole side of the porch was filled. During all this time we had neither seen nor heard again from Uncle Treach. My grandfather said, "Let's go," and we turned from the porch to see my grandmother.

She was coming across the yard carrying the covered basket. "You said he didn't talk bad to you, so I thought maybe it would be all right to come in," she said, looking up at my grandfather.

She looked around. "Where is he?" she asked.

"Hilda," said my grandfather, "Hilda, honey-"

But my grandmother had already started to climb the porch steps, a tentative smile on her face, calling to her brother. "Treach," she said. "Treach, darlin', look what I've brought you." She knocked gently on the door. "It's Sister, Treach. Can I come in?" There was no answer, but she turned the knob and pushed the door inward anyway.

It slammed back in her face. We heard a lock click from inside, and then a peephole in the door snapped open. Uncle Treach's eye appeared in it. Seeing his eye isolated like that, as a framed spot in the doorway, I noticed for the first time what a remarkable eye it was. The most remarkable thing about it was the 
way it glared. I would not have thought it possible for an eye to glare like that by itself, divorced of the context of its face to give it meaning and support, but this eye did it. It was a most imposing eye.

My grandmother regarded it unhappily. "Treach," she said, "I brought you some things for the fall and winter. There's a good smoked ham in this picnic basket, Treach." She raised the basket and held it on a level with Uncle Treach's eye. "See?" she said.

"Hilda," said my grandfather.

My grandmother continued. "We brought a lot of other things for you, Treach. It's all over there, on the porch."

She pointed, positioning her hand just at the level of his eye so he could see it point. "You can't see it because you have your eye in the peephole, Treach, but it's over there," she said.

She and Uncle Treach's eye regarded one another.

"Treach, that eye isn't you," she said at last. "That eye is scowling. That eye is scowling at me, Treach. You aren't scowling at me, are you, Treach?"

Uncle Treach hissed something.

My grandmother's hand came to her mouth. My grandfather took a step toward the door and shook his finger at the eye. "Now see here, Treach," he began.

He was interrupted as the door flew open and Uncle Treach stood forth screaming inarticulately and brandishing a shotgun. My grandfather fastened his arm around his wife and half carried, half propelled her down and out of the yard toward the car. He yelled to me to run, and I did. But though I was going as fast as I could, he was outdistancing me more and more. I yelled for him to wait but he kept going through the open gate. I heard the sound of Uncle Treach's gun. I thought he was shooting at us, so I dropped down and lay on the ground and yelled at my grandfather to wait. He turned back and called for me to get up and come on. But I was afraid to get up and so I lay there and yelled for him to wait and come and get me. I was afraid to even lift my head up to look. All I could see was Uncle Treach's ground in my eye and his cap off to one side where he had thrown it down. I heard my grandfather run back in through the gate. He yanked me up by my shirt collar, lifting me with one arm high enough so that my feet hardly touched the ground. He moved the two of us faster than I could have moved myself. He got into the driver's side of the car and more or less threw me over into the back seat. From the porch came the sound of Uncle Treach's screaming.

As the car turned around, I got up in the back seat and looked back at the house. Just as I looked back, Uncle Treach let fly with the second barrel of his shotgun right into the food on the porch. Bits of glass jars and egg fragments flew up like fireworks, and the dogs, who had been barking around my grandfather's car, wheeled and ran back to the new sound on the porch. Uncle Treach watched until they were within range, and then he hurled the discharged shotgun right into the middle of them. They scattered and ran. Uncle Treach slammed back into the house. We went down over the hill. 